\title{
Recommendations of Ads Text (Writing and Visual) that Can Break the Myth: A Lot of Luck of Having Many Children in Indonesia: The Combination between Semiotic and Sociological Analysis
}

\author{
Muhamad Gibraltar M.Si \\ Department of Communication, School of Communication, International Relations, and Law, President University, Bekasi, Indonesia
}

Email address:

gibraltarmuhammad@gmail.com, gibraltarcommunication51@gmail.com

To cite this article:

Muhamad Gibraltar M.Si. Recommendations of Ads Text (Writing and Visual) that Can Break the Myth: A Lot of Luck of Having Many Children in Indonesia: The Combination Between Semiotic and Sociological Analysis. Humanities and Social Sciences.

Vol. 3, No. 2, 2015, pp. 64-74. doi: 10.11648/j.hss.20150302.11

\begin{abstract}
The Purpose of this study was to design the advertisement consists of the counter myth: A lot of Luck of having only two children (Hanya Mempunyai Dua Anak, Banyak Rejeki) that able to break the "Myth": A lot of luck of having many children (Banyak anak, banyak rejeki) in Indonesia. Moreover, this ads must contain the counter myth: A lot of luck of having two children (Dua Anak, Banyak Rejeki). Afterwards, the myth was transformed into writing and view text using the concept of new poetry, and figure of speech (comparison, and confirmation). Also, the myth was treated into the visual text using the semiotic theory of Roland Barthes, combined with other theoretical frameworks such as The Concreteness of Signifier and Signified, Camera Movement (Arthur Asa Berger), Barker (Color Theories), Darmaprawira and Mas Dian (Local Color Theories), and Mark L. Knapp (Nonverbal Communication). Moreover, There are two kinds of findings at this applied research: the first finding is about the new poetry for the writing ad text, composed by the several figure of speeches, such as: Hyperbole, Anthropomorphism, Personification, Metonymy, and Repetition, and the thought from C. Wright Mills of The Sociological Imagination. Then, the poetry will be equipped with the sixteen scenes (including the recommended duration of time) of visual texts, equipped with the semiotic theory of Roland Barthes, and (again) the Sociological Imagination of C. Wright Mills.
\end{abstract}

Keywords: Myth, Counter Myth, Semiotic, Sociological Imagination

\section{Introduction}

It is the final journey of my academic writing in year 2014, which means I must create "something new" and "something different" from my previous opuses, for the sake of my nation, Indonesia (all my journals have the original Indonesian case). Starting from the first, until the last.

Let's take a look my academic journey from the beginning until the end in 2014. First of all, the opus which discussed about the Indonesian Video Game made by Tanoshi Studio, Depok, Indonesia, named "The Battle of Baratayudha" semiotically (Gibraltar, 2014). Moreover, my second journal article is examining the Natural Extract Fiber Ads through semiotic analysis of Roland Barthes, continued with the $I n$ Depth Interview using the principle of the Discursive Symbolism of Susanne Langer (Gibraltar, 2014: 97-100). Furthermore, my third article is about research proposal which tries to analyze the Indonesian action movie The Raid 2: Berandal using the semiotic tool of Roland Barthes, and the Discursive Symbolism of Susanne Langer (Gibraltar, 2014: page 125-128). Lastly, I broadened the theoretical framework into video music by making my last journal: "The Semiotic Analysis of the Video Music: "Indonesia Bangkit" (Gibraltar, 2014: page 148-155). All in all, I believe that semiotic as the theoretical tool can be used and exploited maximally to analyze video games, music clip, film, and advertisement. As a matter of fact, all of them discussed about myth inside the cultural products (Gibraltar, 2014).

Advertising itself as a study is very important. The reason is nowadays advertising becomes the new religion of modern capitalist society. The reason is advertising (as the commercial speech) becomes the cultural phenomenon whose social significance far exceeds its economic influence. Much more than a simple instrument of manipulation or 
consumer information, advertising has become the predominant mediator between culture and the economy, between people and products. (Jhally, 1990)

In addition, Jhally argues that by selling viewing time to advertisers, television converts audiences into laborers who work for the media in the same way that workers do in a factory. By watching commercial messages on $\mathrm{TV}$, viewers actively create symbolic meaning, but also generate profit for media in return for the wage of entertainment. Through an integration of theory and empirical analysis - including studies of over one thousand TV commercials_-Jhally offers a fresh view of such key concepts as fethisism and valorization. (Jhally, 1990)

Back to the discussion. Suddenly, I remembered that when I was being a postgraduate student at the Master of Communication Science, Department of Communication, Faculty of Social and Political Sciences, University of Indonesia; I asked one of my senior lecturer one question about how to make the social change by using the advertisement semiotically. Then, my senior lecturer smiled at me and answered shortly: "Agi, it is simple, just break the myth inside it?". His explanation inspired me to create this research, particularly to create the recommendation of ads that can break the myth inside the society. It means through this article, I want to prove that ads can be very useful to solve the social problem comprehensively. (The Conversation between one of Senior Lecturer at Department of Communication, University of Indonesia and me, June 10th, 2011)

The same idea appeared when I had a conversation with one of the Indonesian enterpreneur at the Rasuna Said Street. He said to me that the most important thing in research was how to reverse the research from examining and analyzing cultural products, to producing the cultural product, including ad, movie, video game, and music clip, etc. Furthermore, he said that Researches must be able to create something beneficial for the society and ease their daily life. (The conversation between one of Indonesian enterpreneur with me at the Rasuna Said Street, Kuningan, Jakarta, on August 13th, 2014)

"Break the myth!". It is a very brilliant idea. What comes into my mind at that time was creating the ads that contain the "counter myth" that can break the "Myth". Specifically, the formula is like: "Counter Myth vs. Myth".

Every advertisements contains a myth, and it is formed deliberately. From my previous research, whose the unit of analysis was two versions of television advertisement of Natural Extract Fiber Brand $\mathrm{X}$ aired on televisions from 2009-2011. The first version contains the myth of the product was better than natural fruits and vegetables in preventing users from hemorrhoids. In addition, the second ads showed the myth of both products (Citrus and Herbal) were better than Natural Fruits and Vegetables in smoothing bowel movements. (Gibraltar, 2014: 100-103).

Specifically, my goal is forming the counter myth that can break the "Bad" or "Status Quo" Myth. In this case, the counter myth is: "A lot of luck of having only two children"
(Banyak Rejeki karena Hanya Mempunyai Dua Anak"). "Two Kids" is the sum that has been fixed since the first National Planning Program was launched in Indonesia in the New Regime (Orde Baru) Era.

Then, What kind of myth (or the negative myth) that must be broken? Based on my observation, the myth of: A lot of fortune of having many children (Banyak Anak, Banyak Rezeki) is still existed in Indonesia in reality. In fact, the Indonesian family wants is higher rather than 2007 with the fertility rate $2.6 \%$ per mother usually. If someone is asked how many children he / she wants, the answer will be more than 3, perhaps 4 or 5 children per family. Like the answer that told by Mrs. Kadriah, when a I asked her about how many children does she want, she answered: "If I am capable, I want four until five children, but I will see my health condition before I decide". (Ledakan Penduduk di Indonesia Tahun 2035, Bonus atau Ancaman. http://www.gatra.com/nusantara-1/nasional-1/59572-ledakanpenduduk-indonesia-tahun-2035,-bonus-atau-

ancaman $\%$ E2\%80\%8F.html. Accessed at the 28/12/2014).

Unfortunely, this myth creates misfortune for Indonesia in the future. Based on information from the National Family Planning Coordinating Board (BKKBN), it has been predicted that Indonesia will face population explosion in 2035, increase dramatically 100 million people within 10 years. According to the national census in 2010, the sum of Indonesian population was 237,6 million people, and it will raise to 340 millions people in 2035 . This situation will make the bad impact for the workforce in the future, it means people will be more diffult to get a job. Moreover, Indonesia is predicted will face the malnutrition and educational problems (Ledakan Penduduk di Indonesia Tahun 2035, Bonus atau Ancaman. http://www.gatra.com/nusantara1/nasional-1/59572-ledakan-penduduk-indonesia-tahun2035,-bonus-atau-ancaman $\%$ E2\%80\%8F.html . Accessed at the $28 / 12 / 2014$.

One of Indonesian population expert has remarked: "Everyday more than 10.000 babies in Indonesia are born or the population growth in Indonesia is same with the total population of Singapura". Moreover, The chief of The National Family Planning Coordinating Board (BKKBN) said that the the Indonesian growth population is worrying. Absolutely, it will affect the population growth rate. Every year, babies born in Indonesia approximately 4.2 millions. Babies born in Hermina Hospital approximately 6.1, said the dr. Susi Setyawaty The Director of Hermina Hospital. Also, this situation is supported by the alibi of United Nations which sees Indonesia has graduated from the Family Planning Program. So that, it loosens its program. (Rohmatin Bonasir. Ancaman Ledakan Penduduk. http://www.bbc.co.uk/indonesia/laporan_khusus/2010/07/100 706_population $1 . \operatorname{shtml}$. July 8th 2010. Accessed at 28/12/2014)

Other prediction is remarked by Fasri Djalal, the head of National Family Planning Coordinator Board Program. At University of Indonesia, he said that the total population of West Java Province is 45 Million People, and he predicted 
that within the 21 years, the total population of West Java will be exploded. (21. Tahun Lagi, Terjadi Ledakan Penduduk di Jawa Barat. http://www.tribunnews.com/metropolitan/2014/09/20/21tahun-lagi-terjadi-ledakan-penduduk-di-jawa-barat

Accessed at 28/12/2014).

In addition, The Coordinating Minister of Social Welfare of RI, Agung Laksono said that there must be a grand design to anticipate the population explosion. As has been predicted that in 2035, the total population of Indonesian population will reach 305,6 Million People. Moreover, Agung Laksono added that people must be retold that 2 children are enough. (Suryanta Bakti Susila, Nila Chrisna Yulika. Ledakan Penduduk di 2035, Apa yang Harus Dilakukan. http://nasional.news.viva.co.id/news/read/477309-ledakanpenduduk-di-2035--apa-yang-harus-dilakukan. Accessed at 28/12/2014)

To conclude, the final academic journey must be shown by making something concrete, and it must be able to solve the social problem that exist within the society, which can be manifested as breaking the myth: A lot of fortune of having many children (Banyak Anak, Banyak Rejeki), by creating the counter myth: "A Lot of luck of having only two children), because it will create a misfortune for Indonesia in the future, such as: Unemployment, malnutrition, educational problems, etc. As a matter of fact, the counter myth is: "A few of fortune of having many children". (Banyak Anak, Sedikit Rejeki)

Therefore, the main research question for this article is How to create ad texts (writing and visual) that consist of the counter myth: "A Lot of Luck of Having Only Two Children" (Mempunyai Dua Anak, Banyak Rejeki)? Absolutely, if it is transferred into the sentance (Research Problem), it will be creating ad Texts (writing and visual) that consist the counter myth: "A Lot of Luck of Having Only Two Children" (Mempunyai Dua Anak, Banyak Rejeki)?

In order to answer the research question, there are several theoretical frameworks that must be considered.

In my opinion, making ads needs the imagination to connect between the personal troubles of milieu, and public issues of social structure. Why? Ads is created by putting daily activities, conflicts, routines, happiness, sadness, etc (biography) to reach broader audience by using mass communication (history). Therefore, the sociological concept of "Sociological Imagination" of C. Wright Mills will be implemented at this research as the basic foundation.

The Sociological imagination is noted for its distinction between personal troubles and public issues, as well as the objective of linking the two. This concept is reminiscent, within the realm of social problems, of the focus of the character and social structure: The relationship between the private and the public, the innermost acts of the individual with the widest kinds of socio -historical phenomena. (Ritzer, 1996: 64)

Furthermore, personal troubles of milieu is the characteristic of individual, in scope of the relationship with others, and the threat for personal values (biography). In contrast, Public issues of social structure means something that outside the individual boundary, and individual life (History). C. Wright Mills saw that there is a correlation between two of them, and it is described at one of his statements:

"The Sociological imagination enable us to grasp history and biography and the relation between the two within the society" (Mills, 1968: 6)

Move to the concept of the myth. According to the Marcel Danesi, the myth is the ancient story about gods, heroes, and supernatural events; and by extension, any story that aims to explain something in nonliteral or nonscientific ways. (Danesi, 2009: page 206)

In contrast, the counter myth is the myth that counters or contradicts another. (Wiktionary. http://en.wiktionary.org/wiki/countermyth, accessed at the 02 January 2015).

In addition, I will use the concept of new poetry, and figure of speech (comparison and confirmation) to rationalize the imagination and transform it into ad writing text.

New poetry is called the modern poetry. Moreover, its shape is more free, even if the nature of itself is still uphold, such as diction, rhyme, rhythm, etc. (Sadikin, 2010).

Then, to compose sentances particularly, it will be utilized the figure of speech (comparison and confirmation). There are several of them that will be applied in this research (For the Writing Text):

Figure of Speech: Comparison

A. Allegory : Stating with the different ways, through allusion, or description.

B. Antropormorphism : Metaphor that uses words or other configurations that are related to humans to describe something inhuman.

C. Personification: Revealing with submitting inhuman to become human.

D. Metonymy: Revealing with using names or inhuman objects to become brand, identity, and atribute.

\section{And, one of Figure of Speech: Confirmation}

E. Repetition : Reduplication of same words, phrase, and clause at the sentance

(Toha-Sarumpaet, 2002: 34)

Moreover, the imagination needs to be rationalized visually, since advertisement involves gestures, colors, camera movement, sign, etc. Therefore, Roland Barthes' semiotic logical framework will be used for that purpose. (For the visual Text)

If Roland Barthes' thought is described in the form of scheme, it will become as stated below. In brief, this is the "theoretical container" to rationalize the imagination which will become the stepping stone of the analysis in the present research, while other theories (such as the theoretical development of Charon's symbolic interactionism, which later became more specific in Arthur Asa Berger's discussion 
on the concretization of signifier and signified, Barker's thought about the relationship between colors and moods, and Knapp) about nonverbal will become the "analytical knife" which fills the boxes in the scheme created by Roland Barthes, particularly box number 4: "Connotative Signified"; the box in which the interpretation of denotation system is conducted by the semiotic I:

Therefore, the starting point in this research is the "Second Level Signification", more specifically the "Connotative Signified".

At the second level of analysis, there are a number of logical frameworks used to fill in the column number 4 (connotative signified). Subsequently, we will make it concrete with Mark L. Knapp's thought about the nonverbal concept, to the meaning of a color by Barker. The following is their respective narratives based on the matter.

Mark L. Knapp explained that the term nonverbal is usually used to describe all communication events other than said and written words. In this definition, nonverbal events and behavior are not really nonverbal in nature. The nonverbal field is an area which emphasizes the importance of phenomenon which is empirical, factual and concrete in nature, without speech and language. It means that the nonverbal field is related to concrete, real matters which can be proven through human senses. (Wibowo, 2011: 72)

The concretization of this thought is as expressed by Arthur Asa Berger in the following: (Sobur, 2009: 174-175)

Table 1.1. The Concreteness of Signifier and Signified.

\begin{tabular}{ll}
\hline Signifier & Signified \\
\hline 1. Long hair. & Noncompliant with the culture (Especially for \\
2habby hair). \\
2. Neat hair style. & Entrepreneurs. \\
3. Hair cut too short. & Gays and soldiers/both. \\
4. Brick brown. & Fond of sports, leisure activities. \\
5. Pale. & Intellectuals (sick people). \\
6. Levi's. & Casual clothes, the proletariat. \\
7. Designer jeans. & Respected, luxurious. \\
8. K. Mart's jeans. & Workers. \\
9. Three-piece suits. & Executives, entrepreneurs. \\
10. Suitcases. & Old-fashioned, traditional. \\
11. Diplomatic bags. & Typical successful entrepreneurs. \\
12. Handbags. & European style, Italian descents. \\
13. Backpacks. & Nomad. \\
14. Shopping bags. & Farmers. \\
15. Sandals. & Artists. \\
16. Winged. & Typical entrepreneurs. \\
17. Worker's boots. & Workers. \\
18. Nomad's boots. & Nature lovers, wanderers. \\
19. Pilot's glasses. & Middle class. \\
20. Chain glasses. & Geeks. \\
21. Dark/black glasses. & Typical street, crazy people. \\
22. Necktie with knot. & Educated people. \\
23. Thick necktie. & Old-fashioned people. \\
24. Rope necktie. & Provincial people, Westerners. \\
\hline & \\
\hline
\end{tabular}

A. Similarly, concretization of the motion of the camera, shooting, and size of shooting according to Arthur Asa Berger is as follows:
Table 1.2. Size of shooting (Adityawan, 2008: 41)

\begin{tabular}{|c|c|c|}
\hline $\begin{array}{l}\text { Signifier of } \\
\text { Shooting }\end{array}$ & Definition & Signified \\
\hline Close Up & Only the face & Intimacy \\
\hline Medium Shot & Nearly the entire body & Personal relationships \\
\hline Long Shot & Setting and characters & $\begin{array}{l}\text { Context, scope, public's } \\
\text { distance }\end{array}$ \\
\hline Full Shot & The whole body & Personal relationships \\
\hline
\end{tabular}

Table 1.3. Motions of Camera and Substitution (Adityawan, 2008: 41)

\begin{tabular}{lll}
\hline $\begin{array}{l}\text { Signifier of } \\
\text { Shooting }\end{array}$ & Definition & Signified \\
\hline Pan Down & The camera pointing down & Power, authority \\
Pan Up & The camera pointing upwards & Weakness, diminution \\
Dolly In & $\begin{array}{l}\text { The camera moving inwards } \\
\text { The image seen on the blank }\end{array}$ & Observation, focus \\
Fade In & $\begin{array}{l}\text { Beginning } \\
\text { screen }\end{array}$ & Closure \\
Cude Out & $\begin{array}{l}\text { Moving from one image to } \\
\text { another }\end{array}$ & Continuity, interesting \\
Wipe & $\begin{array}{l}\text { The image wiped out from } \\
\text { the screen }\end{array}$ & $\begin{array}{l}\text { "Determination" } \\
\text { conclusion }\end{array}$ \\
\hline
\end{tabular}

Table 1.4. Visual Languages and Importance (Adityawan, 2008: 42)

\begin{tabular}{|c|c|c|}
\hline Sign & Important & Unimportant \\
\hline Size/Scale & $\begin{array}{l}\text { Large } \\
\text { Bigger than the } \\
\text { surroundings }\end{array}$ & $\begin{array}{l}\text { Small } \\
\text { Smaller that/equal to the } \\
\text { surroundings }\end{array}$ \\
\hline Position & $\begin{array}{l}\text { Center } \\
\text { Front } \\
\text { Top } \\
\text { Upper-Left hand }\end{array}$ & $\begin{array}{l}\text { Edge } \\
\text { Back } \\
\text { Bottom } \\
\text { Lower-Right hand }\end{array}$ \\
\hline $\begin{array}{l}\text { Angle/Position of } \\
\text { Camera }\end{array}$ & Under the Object & Above the Object \\
\hline $\begin{array}{l}\text { Figure/Object } \\
\text { Light }\end{array}$ & Light & Dark \\
\hline Background Light & Light & Dark \\
\hline $\begin{array}{l}\text { Focus/Depth of } \\
\text { Field }\end{array}$ & Clear/Sharp & Unclear/Blurred \\
\hline $\begin{array}{l}\text { Frequency of } \\
\text { Appearance }\end{array}$ & Often Appears & Rarely Appears \\
\hline Accent & $\begin{array}{l}\text { Different from the } \\
\text { surroundings }\end{array}$ & $\begin{array}{l}\text { Same as the } \\
\text { surroundings }\end{array}$ \\
\hline
\end{tabular}

The last one is related with colors. Everybody certainly has a favorite color. And usually, this color affects their mood. The following is a description of mood associated with colors as stated by Barker (1954). (Sobur, 2009: 174-175)

Table 1.5. Color-Associated Moods.

\begin{tabular}{ll}
\hline Mood & Color \\
\hline Exciting, stimulating & Red. \\
Safe, comfortable. & Blue. \\
Depressed, disturbed, confused. & Orange. \\
Soft, soothing. & Blue. \\
Protecting, defending. & Red, Brown, Black. \\
Very sad, heartbroken, unhappy. & Black, Brown. \\
Calm, peaceful, serene. & Blue, Green. \\
Dignified, noble. & Purple. \\
Fun, cheerful, happy. & Yellow. \\
Challenging, resisting, hostile. & Red, Orange. \\
Powerful, strong, excellent. & Black \\
\hline
\end{tabular}


The element of color is a fundamental element in the visualization of commercials. Colors play an important role in creating the meaning of a commercial, particularly in terms of emotion and feeling. In art, the use of symbolic colors is an event considered important. According to Darmaprawira, several colors which have symbolic values in general are, among others: (Darmaprawira, 2002: 45-49)

Red: Of all the colors, red is the strongest and most attractive color, which is aggressive in nature and symbolizing the primitive. This color is associated with blood, anger, bravery, sex, danger, strength, virility, love, and happiness.

Purplish Red: The purplish red color has the characteristics of noble, glorious, rich, proud (arrogant), and impressive.

Purple: The characteristics of this color are cool, negative, backward, almost similar to blue but deeper and more solemn, and it has a gloomy and submissive character. This color symbolizes sorrow. It is contemplative, sacred, and a religious symbol.

Blue: It has cool, passive, calm and peaceful character; Goethe named this color as a dazzling, spiritual, monotheistic, and lonely color, which thinks about the past and future in the present. Blue is a perspective color, which draws us to solitude, chill, separation, and creates distance. Blue symbolizes the sacredness of hope and peace.

Green: It symbolizes contemplation, belief (religion) and eternity. It also expresses freshness, rawness, youth, immaturity, growth and hope, rebirth and fertility. The negative side of green is that it is disliked by children, associated with the color of diseases, hatred, venom, and jealousy.

Yellow: It symbolizes pleasure, agility and intellectuality, and also symbolizes the glory of love and deep understanding in interpersonal relationship.

White: It has positive, stimulating, bright, light and simple character, and it also symbolizes sacredness, innocence, honesty and purity.

Grey: It symbolizes calmness, politeness and simplicity. It also symbolizes intelligence, but it has a negative epitome of indecision. Its neutral character symbolizes a mediator in conflicts.

Black: It symbolizes darkness and the absence of light. It indicates dark force, the symbol of mystery and the color of the night. It is also often symbolized as the color of destruction or mistake. Black can also indicate a firm, robust, and formal attitude as well as a strong structure.

Furthermore, Mas Dian, a Feng Shui consultant, in his book "The Impact of Colors in Feng Shui" which was published in 2002, proposed that colors have characteristic that unequivocally affects a person's psychological condition and may provide various inspirations which stir the emotions. He also elaborated that the language of colors has different meanings, such as, among others (Dian, 2002: 1-2):

Pink: describing a feminine, soft, tender, beautiful and romantic character.

Red: symbolizing an energetic, mighty, dynamic, active and hot character.

Beige: symbolizing a soft, classic, exclusive, neutral, warm and sweet character.

Orange: describing a cheerful, popular, hard, bright, hot and fervent character.

Light Yellow: representing a cheerful and happy, bright, warm, soft, beautiful and sweet character.

Light Green: describing a fresh, happy, cheerful, and growing character.

Green: describing a classic, cool, worldly, exclusive and calm character.

Light Blue: symbolizing a calm, clean, cool, peaceful, gentle and relaxed character.

Blue: describing a classic, strong, confident, calm and professional character.

White: describing a calm, pure, clean, sacred, classic, sparkling and sorrowful character.

Black: symbolizing a classic, elegant, mystical, strong, hard, sexy and dramatic character.

Silver: describing an exclusive or expensive, elegant, classic and cool impression.

Gold: symbolizing an energetic, mighty, dynamic, active and hot impression.

The inclusion of these logical frameworks is quite important considering that there are various aspects to be analyzed in a commercial namely, in addition to words, also pictures and even the movements of each actor appearing in the commercial. The concepts of nonverbal, kinesthetic, and association between moods and colors are extremely important to be included considering that advertisement are not only displaying signs, but also various kinds of languages and grammars, movements of the commercial's actor, and a number of colors which send certain messages to the viewers who watch it.

As the result, it can be ensured that the thought of Darmaprawira and Mas Dian is extremely necessary as the analytical tool in this research.

The connecting line is that the important aspects to be studied in the research on advertisements are the aspects of color, dialogue and nonverbal.

The theoretical container will be explained like this: (Page 10) 


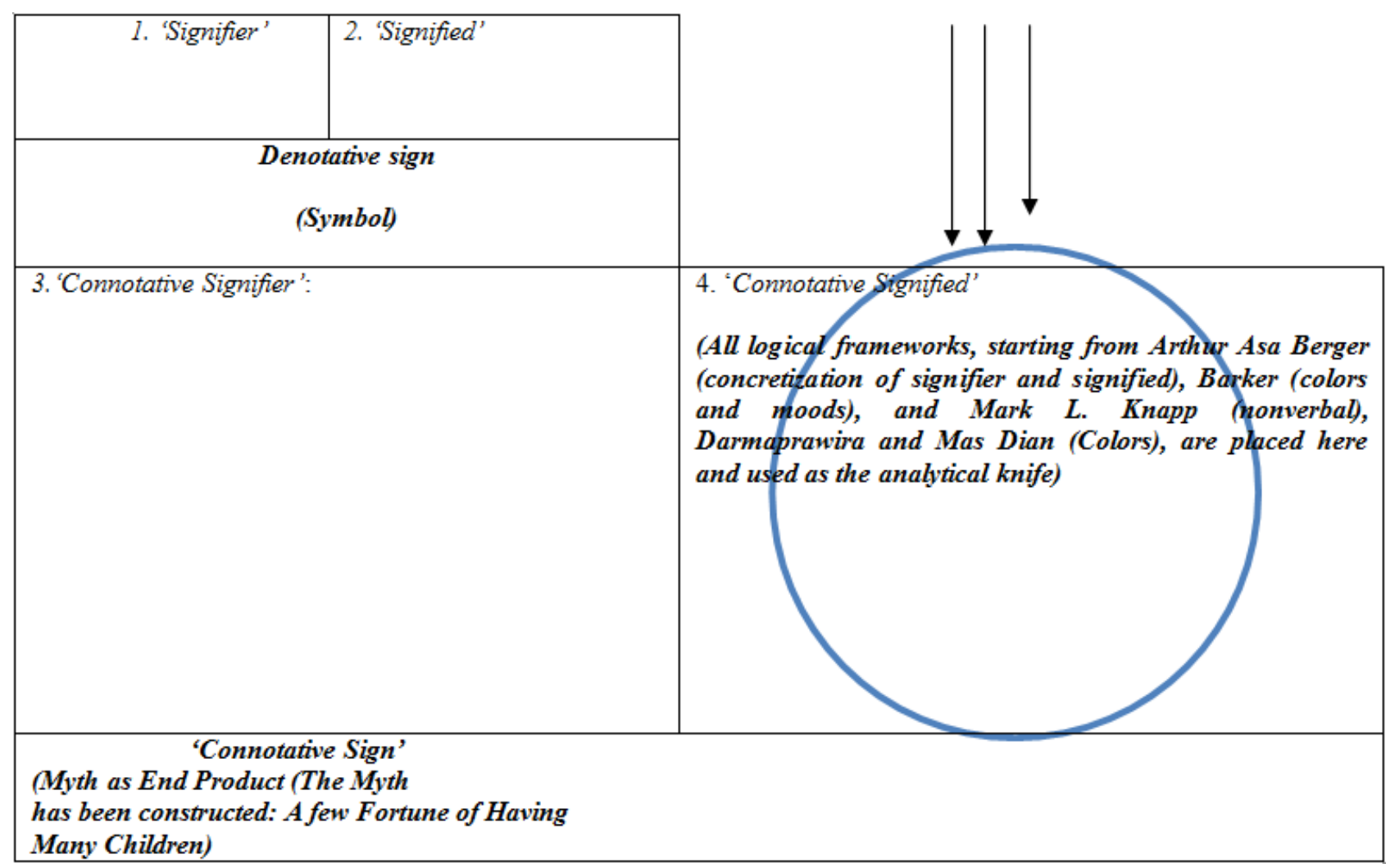

(Gibraltar, 2014: 97) and (Gibraltar, 2012: 44)

Diagram 1.1. The Theoretical Container.

As a matter of fact, the usage of C. Wright Mills Thought, New Poetry, The Figure of Speech (Comparison, Confirmation), and the Semiotic theory of Roland Barthes is purposed to create the good advertisement, characterized by several points:

\section{A. Get Attention.}

B. Show People an advantage.

C. Prove it.

D. Persuade people to Grasp this advantage.

E. Ask for action

(Schwab, 1962: page 1)

Moreover, the researcher will dramatizes the facts, and present them from the point of view of consumer to present the facts in advertising, and prove the facts (Schwab, 1962: page 76). Other criteria will not be used like: Be Specific, since there were several ads like Nutrilon Royal 3: Life is an
Adventure which was not too specific, but gain the very good popularity for the Indonesian,s audience. (Gibraltar, 2011: page 8 )

In conclusion, the academic Journey of myself in 2014 must be ended by creating something extraordinary. It means must create the recommendation of good ads that consist of myth: The Little Fortune of Having Many Children in order to break the previous myth: A Lot of Luck Of Having Many Children. In order to make it happen, it is utilized the sociological imagination of C. Wright Mills, after we grasp the imagination, it will be continued to The Concept of New Poetry and Figure of Speech (To create Ad Writing Text), and The Semiotic Thought of Roland Barthes (To create Ad Visual Text).

The diagram of the theoretical foundation for this journal is like this (How to make the television ads based on Muhamad Gibraltar (Myself) thought): 
STEP ONE:

CREATING THE COUNTER MYTH:

A LOT OF LUCK OF HAVING ONLY

TWO CHILDREN (MEMPUNYAI

BANYAK REJEKI JIKA HANYA

MEMPUNYAI DUA ANAK) TO

BREAK THE MYTH:

A LOT OF LUCK OF HAVING MANY

GHILDREN.

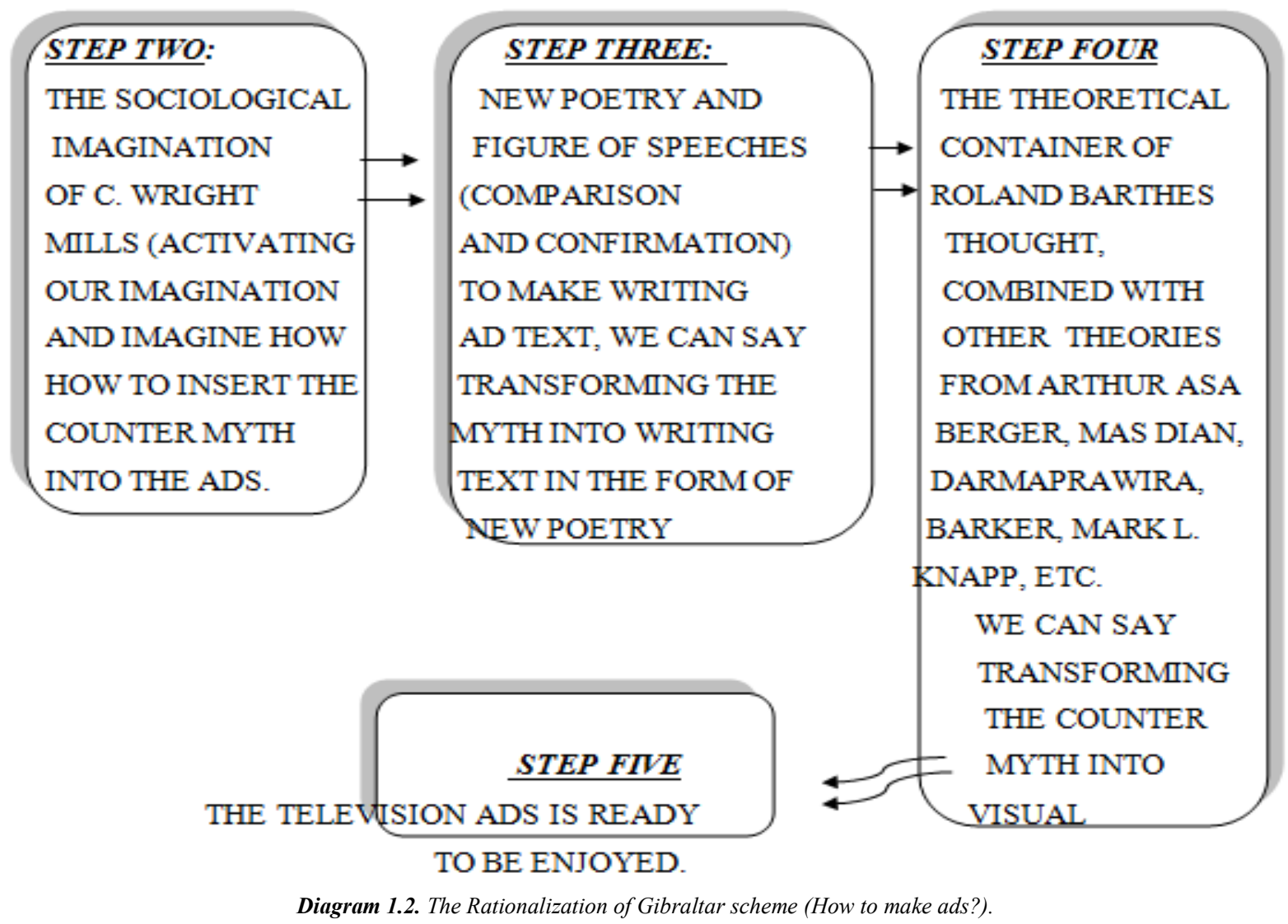

\section{Research Methods}

This present study use an interpretive paradigm by utilizing the literature review method. Furthermore, correlating with the seriousness / relevance, there must be "Goodness Criteria" (Seale et all, 2007: 377). The I took five aspects to guarantee the quality of this research. They are:

A. Completeness of Descriptions: This research explained how to make an ads that can break the myth: A lot of luck of Having Many Children by using the counter myth: A few fortune or luck of having many children, using the antonym of word. The diagram 1.2 has explained about the complete description about this journal.

B. Authenticity: I (myself) transform the counter myth into the writing and visual text by his own original idea. Moreover, the diagram 1.2 is also his original idea.

C. Ecological Validity and Credibility: The mission of this journal to break the myth: A lot of luck of having many children is similar with the overcoming the social problem in Indonesia, and I believe it fits with the "Indonesian Ecology". Hopefully, in the future, advertising will have the maximum role to overcome the social problems in Indonesia.

D. Plauseability: The I use the two big theories and one big concept that all of them are on track in making ads that can break the myth, and containing the counter myth. Starting from the Sociological Imagination of C. Wright Mills, after that the concept of new poetry and figure of speeches, lastly the semiotic theory from Roland Barthes as the theoretical container, combined with the thought from 
Darmaprawira and Mas Dian (local color theories), Mark L. Knapp (nonverbal communication), Arthur Asa Berger (Concreteness of the signifier and signified, camera movement), and Barker (color theories).

These five aspects have a clear bound with other part. Because they guarantee the quality of this research, starting from the holistic explanation how to break the myth at the Sub Chapter 3.1 and 3.2 (Completeness of Descriptions), the core concepts (myth and the counter myth), the transformation of counter myth into ad text using figures of speeches at the chapter 1 (Authenticity), the suitability with the social need of Indonesia as the one of the most populous countries in the world at the chapter 1 (Ecological Validity and the Credibility), and the combination between the humanities and social sciences with the reasonable scientific explanation Sub chapter 3.1 and 3.2 (Plausibility).

Unfortunately, there is a weakness at this research. It does not involve the music, including the musical notes, for the musical backsound. It is just only, the writing, and the visual text.

For the person's backsound, it is necessary to present the famous public figures, who come from two-kids family or less, to create the concrete example for the audience.

\section{Results and Discussion}

At this chapter, I will discuss about step three, and step four only. Since step one and step two has been discussed at the previous chapters.

\subsection{The Writing Ad Text at the New Poetry Pattern}

Moreover, the researcher has made the poetry for the writing text: (Both in Bahasa Indonesia, and English Version) It is from the previous unpublished Research in 2011, with a few modifications (Gibraltar, 2011: 65). I believe, it is contained the counter myth: A lot of luck/fortune of having only two children, in order to break the "Myth": A lot of luck / fortune of having many children).

Particularly, the core of the counter myth is placed at the sentance number 8 .

\section{(BAHASA INDONESIA VERSION)}

GENERASI INDONESIA HEBAT (NEW POETRY)

(1.) Kami adalah orang-orang yang berada di puncak dunia (Hyperbole, Personal Troubles of Milieu)

(2.) Yang Senantiasa Menggenggam Dunia Dengan Begitu Mudah (Hyperbole, Personal Troubles of Milieu)

(3.) Menantang Ombak, Melaluinya Dengan Cantik, Menjadi Pemenang Bukannya Pecundang (Hyperbole, Personal Troubles of Milieu)

(4.)Menyentuh Langit Penuh Keyakinan (Hyperbole), Menjunjung Tinggi Mahakarya (Allegory, Personal Troubles of Milieu)

(5.) Layaknya Pendaki Gunung, Yang Tidak Hanya Duduk di Kaki Gunung dan Bersenandung di Mulut Sungai (Antropomorphism, Personal Troubles of Milieu)
(6.) Namun Bercengkerama dengan Curamnya Tebing, Bercanda Dengan Maut, Demi Menggapai Impian (Hyperbole, Personal Troubles of Milieu)

(7.) Ingin Seperti Saya, Ingin Seperti Kami, dan Kita Semua (Repetition, Personal Troubles of Milieu)

(8.) Atur dan binalah keluarga anda (Personal Troubles of Milieu), sambil bertekad: "DUA ANAK CUKUP" (Public Issues of Social Structures).

(9.) Agar Mencapai Masa Depan yang Membanggakan Seperti Kami. (Personal Troubles of Milieu)

(10.) Ciptakan, Generasi Super (Metonymy, Public Issues of Social Structures).

(11.) Demi Indonesia, Yang Berprestasi (Public Issues of Social Structure.

In addition, it is the translation to English Version:

\section{ENGLISH VERSION}

THE GENERATION OF GREAT INDONESIA (NEW POETRY)

(1.) We are people at the top of the world (Hyperbole, Personal Troubles of Milieu).

(2.) Who Usually Grasping the Globe So Easily (Hyperbole, Personal Troubles of Milieu).

(3.) Challenging Wave, Passing It Through Beautifully, Becoming Winner, Not A Looser (Hyperbole, Personal Troubles of Milieu).

(4.) Touching the Sky with Full of Confidence, Upholding Magnum Opus (Allegory, Personal Troubles of Milieu).

(5.) Like Climbers, Not Just Relaxing at the Foot of Mountains, and Humming at The Riverside (Hyperbole, Personal Troubles of Milieu).

(6.)But mingling with The Steepness of Canyon, Joking with Death, To Reach The Dream (Hyperbole, Personal Troubles of Milieu).

(7.) Want To Be Like Me, Want to be like us! (Repetition, Personal Troubles of Milieu)

(8.) Manage Your Family (Personal Troubles of Milieu), Then Promise: Two Children Are Enough (Public Issues of Social Structure)!

(9.) To Reach Outstanding Future Like We Did (Personal Troubles of Milieu).

(10.) Create the Super Generation (Metonymy, Public Issues of Social Structures)!

(11.) For The Sake of Glory for Indonesia (Public Issues of Social Structure).

\subsection{The Visual Text Which Accompanies The Writing Text}

Let's make it simple! There are 11 sentances on the poetry, and I want to make 16 scenes based on sentances on the poetry (One for the introduction, 13 for the main ingredients of the ads, and two last scenes for the closing. At least, one sentance will be represented by one visual text. Furthermore, all elements of visual texts must be original from Indonesia (such as, rivers, mountain, seashores, etc).

The researcher is not an artist, or animator, so that through this journal, there will be no the story board, drawn by the hand of the researcher. But, hopefully, the qualitative explanation done by the researcher itself is sufficient to 
answer the research question. However, the researcher believes that it will become the breakthrough about how make a television ads using the new poetry as the writing text

First of all, the introduction must be the image of beautiful scenery from one of forest from West Papua, Indonesia, near the Mount Jayawijaya. Moreover, the camera must be pan down, starting from the sky and cloud, and ending at the forest. The introduction must be approximately 3-4 seconds. Moreover, it will show the power or authority of imagination. It means, children from two kids-family will has the vast imagination at his/her mind, as vast as the sky, and the forest near Mount Jayawijaya. Mount Jayawijaya is choosen because it is the highest mountain in Indonesia, specifically the Cartenz Pyramid (Puncak Jaya) with the (4884 metres above the sea level).

Move to the second scene (Personal Troubles of Milieu), afterwards, the first sentance: "Kami adalah orang-orang yang berada di puncak dunia (We are people at the top of the world)" will be spoken. The scene must be the Cartenz Pyramid (Puncak Jaya), equipped with the fog that surround it, in order to dramatize the fact. In addition, the camera move from the left, to the right. The actor or actress must be presented at the Cartenz Pyramid; then, they will shout the first sentance of the poetry. The duration will be 2-3 seconds. Moreover, it will show by having two children, parents will usher them to the peak of their career easier than any other kids connotatively.

The color and texture of costume is not very important, as long as it should be the cloak since the weather must be very cold, but the researcher believe that the red (bravery), white (purity), or blue (calmness) are the best color in that scene.

Then (the third scene), it is continued with the scene that goes into the sky, and above the sky until it will be seen the earth in the space. The duration approximately 2 seconds.

The fourth scene (Personal Troubles of Milieu), the earth will be grasped suddenly by the right hand of actor or actress, in order to dramatize the fact. Then, he or she will speak: "Yang Senantiasa Menggenggam Dunia dengan Begitu Mudah (Who usually grasping the globe so easily)". Also, to dramatize the fact, the actor or actress must be stand at the peak of highest building in Jakarta: Wisma 46 Building, which has the form like a tip of pen. Connotatively, it will tell that the two kids family will have children to whom they can reach the success easier than other kids in the future. The camera moves from Close up (the palm which grasping the earth), to the long shot (Shotting the man who stand at the peak of Wisma 46 Building). The costume is the sky blue shirt, with the slimfit black trousers or skirt, tie, etc. The duration will be 3-4 seconds.

Afterwards, it is cut again, and move to the fifth scene (Personal Troubles of Milieu). The scene must be taken at the Kampar River, Riau. The surfer speaks: "Menantang Ombak, Melaluinya Dengan Cantik, Menjadi Pemenang Bukan Pecundang (Challenging waves, passing it through beautifully, Becoming Winner not Looser). Then, he or she surfs, passes through the wave beautifully, in order to dramatize the fact. The camera must move from left to right, take a picture of the surfer comprehensively. Kampar River is choosen because it has the seven Bono Waves / Seven Ghost Waves that can desstroy canoes or bigger boats. Connotatively, it shows kids from two kids family will able to overcome every difficulties easier than any other kids. Since it needs longer time to pass through the waves, it needs roundabout 5-6 seconds.

Move to the sixth scene (Personal Troubles of Milieu). Cut again! Then, move to the airplane scene (inside the airplane), and one of actors / actress is the academician / famous diplomat, etc (the costume must be formal such as the black formal coat, with red, blue, or white tie, wearing glasses, etc), and who sits near the window, and touch his / her palm at the glass of the airplane, and speaks: "Menyentuh Langit Penuh Keyakinan, Menjunjung Tinggi Mahakarya (Touching the Sky with Full of Confidence, Upholding Magnum Opus)". The camera is at the position of the Medium Shot, then move to Full Shot (The Hand of actor / actress that palpates the airplane glass). The time needed is roundabout 3-4 seconds.

After that, seventh scene (Personal Troubles of Milieu). Cut again! Move to another scene. The actor / actress must be the climber, and climbing the steep hill (The actor / actress costume must be tight, long hair for the woman, and the color must be red or blue). The camera is at the position of Medium Shot, and he / she will say: "Layaknya Pendaki Gunung, Yang Tidak Hanya Duduk di Kak Gunung, dan Bersenandung di Mulut Sungai (Like Climbers, Not Just Relaxing at the Foot of Mountains, and Humming at The Riverside). Since it needs longer time to portray the condition of climbing the reef, it needs approximately 5-6 seconds.

Then, move to Eighth Scene (Personal Troubles of Milieu), he or she will say: "Namun Bercengkerama Dengan Curamnya Tebing, Bercanda Dengan Maut, Demi Menggapai Impian" (But mingling with The Steepness of Canyon, Joking with Death, To Reach The Dream). After that, he / she slips and almost fall, but his / her hand can hold the other side of the cliff. The Camera is at the position of medium shot. All of them is made to dramatize the fact. Like the previous scene which needs longer time, it needs 5-6 seconds to describe the slip process and dramatize it to get audience attention.

Both scenes contain the message that children from the two kids family is able to face any difficulties and has the risk taking behavior rather than any other kids connotatively.

For the ninth scene (Personal Troubles of Milieu), all actors and actresses (from the beginning) wil speak consecutively. For instance the first, second, and third will say "Ingin Seperti Saya (Want to be Like Me?)", then followed by The Tenth scene (Personal Troubles of Milieu), all of them speak simultaneously: "Want To be Like Us?". Connotatively, audience will ask inside their mind about what will be the next scene. Since it is the short process, the time needed will be shorter, approximately 3-4 seconds.

Move to the Tenth scene (Personal Troubles of Milieu for the first sentance, and Public Issues of Social Structure for the second sentance), the doctor (must be a woman, and wear the white dress, with the shoulder length hair) moves in front 
of the camera (medium shot) and speaks "Atur dan Binalah Keluarga Anda, Sambil Bertekad Dua Anak Cukup (Manage Your Family, Then, Promise Two Children are Enough!”). Connotatively, it shows by having only two children, parents will design the best future for their children. Approximately, it needs 4-5 seconds to describe

For the eleventh scene (Personal Troubles of Milieu), the researcher believes that the scene must be all actors and actresses speak simultaneously: "Agar Mencapai Masa Depan yang Membanggakan Seperti Kami (To Reach The Outstanding Future Like We Did)". The camera must be at the position of the Long Shot. Connotatively, it tells audience the same as the previous message: By having only the two children, parents will design the best future for their children. The duration will be 2-3 seconds.

Next, The Twelfth Scene (Public Issues of Social Structure), The most muscular actor speaks: "Ciptakan Generasi Super (Create The Super Generation)!”. The Camera must at the position of Middle Shot. The duration will be 2-3 seconds.

After that, the thirteenth Scene (Public Issues of Social Structure), the actor or actress whose profession is an academician speaks: "Untuk Indonesia Yang Berprestasi (For The Sake of Glory Indonesia)". The Camera must be at the position of Middle Shot. The duration will be 2-3 seconds.

From the first scene until the thirteenth scene are created to present the facts based on the consumer point of view, since all actors and actresses must be from the two kids families, and gain success at their career journey. Moreover, it must be stated or written the information of actors and actressess, specifically their names, occupation, and label that they are from the Two Kids Family.

Lastly, for the Fourteeth Scene, it contains the statement: "Iklan ini Dipersembahkan Oleh (This ad is devoted by)" for the duration of 3 seconds, and for the Fifteenth Scene: "Iklan ini Didukung Oleh: (This ad is supported by)", also, for the duration of 3 seconds. The background must be white, to show the purity of the information provided.

In conclusion, there are several points that can be summarized:

A. For the costumes, the color of red (bravery), blue (calmness), and white (purity) dominates the advertisements.

B. The total duration of the ads is 47 seconds to 48 seconds. But it is the rough estimation. Yet, the researcher believes It can be broadened into more than 1 minutes, to maximize the myth effects. It means every scenes is added 1 minute.

C. From the first scene until the last scene this ad needs three different places (Cartenz Pyramid, Wisma 46 Building, and Kampar River), one steepy cliff (the location must be in Indonesia), and various actors and actresses / public figures whose from two kids family in order to maximize the counter myth: A lot of Luck / Fortune of having only two children.

D. Mostly, the purpose of this ads is to dramatize the achievement of the actor or actress within their career ("prove it" principle), and view the fact, based on consumer interpretation.

\section{Conclusion}

This research paper is prepared to show the academic community, and practitioners that the semiotic study can be used to design the advertising that contain the counter myth: A lot of luck of having only two children, which can break the myth: A lot of luck / fortune of having many children, as long as it is combined with other thoughts and concepts comprehensively.

Based on the data (qualitatively, and quantitatively), this myth can create multiple social problems, therefore it needs to be solved immediately.

The basic idea appeared when the researcher studied at the Master of Communication Science, Department of Communication, University of Indonesia. In addition, the researcher at that time talked to one of senior lecturers about the advertisement that can solve the social problems, and the lecturer remarked: "Break the myth". The similar moment happened when the researcher chat with the one enterpreneur at Kuningan, Jakarta, Indonesia. Moreover, he proposed to reverse the principle of the research, from examining unit of analysis, into engineering the cultural industry products, including advertisement, film, music clip, video game, etc.

The recommended pattern will be Counter Myth (A lot of luck of having only two children) vs. Myth (Alot of luck of having many children). In the end, the counter myth (Hanya Mempunyai Dua Anak, Banyak Rejeki) will win against the previous myth (Banyak Anak, Banyak Rejeki).

The main research question is: How to make an ads (Writing and Visual Text) that consists the counter myth: A lot of Luck of Having Only Two Children (Mempunyai Hanya Dua Orang Anak, Banyak Rejeki), that can break the Myth: A lot of Luck of Having Many Children (Banyak Anak, Banyak Rejeki)? If it is transferred into the research problem, it will be: Making ads (Writing and Visual Ads) that consists the counter myth: A lot of Luck of Having Only Two Children (Mempunyai Hanya Dua Orang Anak, Banyak Rejeki) that can break the myth: A lot of Luck of Having Many Children (Banyak Anak, Banyak Rejeki).

To answer it, The Sociological Imagination of C. Wright Mills that connect between The Personal Troubles of Milieu, and Public Issues of Social Structure will be the appropriate first foundation. Since designing the ads needs the very good imagination.

Moreover, to arrange the writing ad text, it will be used the concept of the New Poetry, combining with the figure of speeches: Allegory, Anthropomorphism, Metonymy, Personification, and Repetition. Furthermore, to make the visual ad text, the Roland Barthes semiotic framework will be used, combined with the other thought such as: Darmaprawira, and Mas Dian (Local Color Theories), Arthur Asa Berger (The Concreteness of Signifier and Signified), Mark L. Knapp (Nonverbal Communication), etc.

The research method is the Literature review. But, this research does not present the music that accompany the ads. 
Moreover, all the actors / actressess must come from the two kids-family.

For the writing ad text, most of the texts can be classified as the Personal Troubles of Milieu, only the eighth, tenth, and eleventh sentance can be classified as the Public Issues of the Social Structure. In addition, five sentances uses hyperbole, one sentance uses allegory, one sentance uses repetition, and one sentance uses metonymy, and 3 sentances do not use anything.

In addition, for the visual texts, it contains 16 scenes, dominates with the blue, red, and white for the costume, the duration is $47-48$ seconds but it can be prolong to more than one minute to intensify the myth effect, locates at three different places and one steepy cliff in Indonesia, and dramatizes the fact, and is made according to the consumer insight, and dominates with the Personal Troubles of Milieu (Public Issues of Social Structures are only positioned at the 10th, 12th, and 13th scene).

\section{References}

[1] Adityawan, Arief. (2008). Propaganda Pemimpin Politik Indonesia. Jakarta: LP3ES.

[2] Bonasir, Rohmatin. Ancaman Ledakan Penduduk.http://www.bbc.co.uk/indonesia/laporan khusus/20 10/07/100706 population1.shtml. July 8th 2010. Accessed at $28 / 12 / 2014$

[3] Danesi, Marcel. (2009) Dictionary of Media and Communications, New York: M.E. SHARPE

[4] Denzin, Norman K. (1991). Images of Postmodernity: Social Theory and Contemporary Cinema.London: SAGE PUBLICATIONS. Dian, Mas. (2002). Pengaruh Warna dalam Feng Shui. Jakarta: PT. Elek Media Komputindo.

[5] 21. Tahun Lagi, Terjadi Ledakan Penduduk di Jawa Barat. http://www.tribunnews.com/metropolitan/2014/09/20/21tahun-lagi-terjadi-ledakan-penduduk-di-jawa-barat . Accessed at $28 / 12 / 2014$

[6] Gibraltar, Muhamad. (2014). Viewers Interpretation of Myth: The Semiotic Analysis of the Natural Extract Fiber Brand X Commercials Aired On Televisions From 2009-2011. Journal of Humanities and Social Sciences, Science PG, July 10th, 2014.

[7] Gibraltar, Muhamad (2014). Comparison Between Interpretation of Viewers in Cultural and in Industrial Cities on The Myth: A Semiotic Analysis of the Indonesian Action Film The Raid 2: Berandal. Journal of Humanities and Social Sciences, Science PG, Sebtember 10th, 2014.
[8] Gibraltar, Muhamad (2014). A Semiotic Analysis of The Video Music: "Indonesia Bangkit": Comparing Audience Interpretation. Journal of Humanities and Social Sciences, Science PG, October 30th, 2014.

[9] Gibraltar, Muhamad (2014). Gamers Interpretation of Myth: A Semiotic Analysis of the Local Video Game: The Battle of Baratayudha. International Conference of Business, Management, and Social Sciences, Grand Inna Kuta Bali. Conference Procedings.

[10] Gibraltar, Muhamad (2012). Interpretasi Pemirsa Terhadap Penanda dan Petanda (Analisis Semiotika Iklan Sari Serat Alami Merek X di Televisi antara Tahun 2009-2011). Jakarta: Magister Ilmu Komunikasi UI.

[11] Gibraltar, Muhamad (2014). Analisis Wacana Iklan Nutrilon Royal 3: Life is an Adventure Hingga Rekomendasi Teks Iklan Tandingan Berbentuk Puisi Baru Menggunakan Semiotika Roland Barthes, Dalam Rangka Mematahkan Mitos Susu Formula Lebih Baik Dibandingkan Dengan ASI. Bekasi: President University.

[12] Jhally, Sut. (1990). The Codes of Advertising: Fethisism and The Political Economy of Meaning in The Consumer Society. New York: Routledge.

[13] Ledakan Penduduk di Indonesia Tahun 2035, Bonus atau Ancaman. http://www.gatra.com/nusantara-1/nasional1/59572-ledakan-penduduk-indonesia-tahun-2035,-bonusatau-ancaman $\%$ E2\%80\%8F.html . Accessed at the 28/12/2014

[14] Schwab, Victor. How to Write A Good Advertisement: A Short Course in Copywriting. California, 1962.

[15] Sarumpaet, Toha (2002). Apresiasi Puisi Remaja: Catatan Mengolah Cinta. Jakarta: PT. Gramedia Widiasarana.

[16] Sulasmi, Darmaprawira. (2002). Warna: Teori dan Kreativitas Penggunaannya: Edisi Kedua, Bandung, Institut Teknologi Bandung.

[17] Sobur, (2009), Alex. Semiotika Komunikasi. Bandung: PT. Remaja Rosdakarya.

[18] Sunarto, Kamanto. (1993). Pengantar Sosiologi. Jakarta: Lembaga Penerbit Fakultas Ekonomi Universitas Indonesia.

[19] Wibowo, Indiwan Seto Wahyu. (2011). Semiotika Komunikasi: Aplikasi Praktis Bagi Penelitian dan Skripsi Komunikasi. Jakarta: Mitra Wacana Media.

[20] Wiktionary. http://en.wiktionary.org/wiki/countermyth, accessed at the 02 January 2015

[21] Yulika, Chrisna, Susila. Ledakan Penduduk di 2035, Apa yang Harus Dilakukan. http://nasional.news.viva.co.id/news/read/477309-ledakanpenduduk-di-2035--apa-yang-harus-dilakukan. Accessed at 28/12/2014) 